\title{
Malignant lymphoma associated with Behçet's disease: A report of 2 cases
} Aynı hastada Behçet hastalı̆̆ı ve malign lenfoma birlikteliği: İki olgu sunumu

\author{
Ahmet Deniz Meydan¹, Bilge Gürsel ${ }^{1}$, Nilgün Özbek ${ }^{1}$, Bilge Can² ${ }^{2}$ Bedri Kandemir² \\ ${ }^{1}$ Department of Radiation Oncology, Faculty of Medicine, Ondokuz Mayıs University, Samsun, Turkey \\ ${ }^{2}$ Department of Pathology, Faculty of Medicine, Ondokuz Mayls University, Samsun, Turkey
}

\begin{abstract}
Herein we report 2 cases of malignant lymphoma associated with Behçet's disease. Case 1, a 53-yearold man, was diagnosed as Behçet's disease at the age of 26 years, and was treated with cyclophosphamide and prednisolone. At 45 years of age, bilateral enlarged lymph nodes were observed in the patient's neck. Evaluation of a lymph node biopsy specimen showed Hodgkin's disease and chemotherapy was administered. Due to disease recurrence 7 years later, chemotherapy and radiotherapy were administered. Case 2, a 67-year-old male, was diagnosed as Behçet's disease at age 44 years and began colchicine treatment. At 60 years of age a mass in his left tonsillar fossa was noted. Evaluation of a left tonsil biopsy specimen showed malignant lymphoma. Radiotherapy and chemotherapy were subsequently administered. At the time this report was written both patients were disease-free. Malignant lymphoma associated with Behçet's disease is rare-only 17 cases have been published. In addition to the presented cases, the literature regarding malignant lymphoma associated with Behçet's disease is reviewed. (Turk J Hematol 2011; 28: 327-34)
\end{abstract}

Key words: Behçet's disease, malignant lymphoma, radiotherapy, morbidity

Received: August 25, 2010

Accepted: March 5, 2011

Özet

Bu yazıda, Behçet hastalığı ile birlikte bulunan iki malign lenfoma olgusu sunulmuştur. Elli üç yaşındaki ilk olguya 26 yaşında Behçet hastalığı tanısı konmuş ve üç yıl siklofosfamid ve prednizolon ile tedavi edilmiştir. Kırk beş yaşında boyunda lenf nodları tespit edilmiştir. Lenf nodu biyopsisi sonucu Hodgkin hastalığı tanısı konmuş ve kemoterapi uygulanmıştır. Yedi yıl sonra hastalık relapsı nedeniyle kemoterapi ve radyoterapi uygulanmıştır. Altmış yedi yaşındaki ikinci olguya 23 yll önce Behçet hastalığı tanısı konmuş ve kolsişin başlanmıştır. Altmış yaşında sol tonsiller fossada kitle saptanmıştır. Sol tonsilden alınan biyopsi sonucu malign lenfoma tanısı konmuş, radyoterapi ve kemoterapi uygulanmıştır. Her iki hasta da lenfoma açısından hastalıksız izlenmektedir. Aynı hastada bu iki farklı 
hastalığın birlikteliği nadirdir. Literatürde bu birliktelik sedece 17 olguda bildirilmiştir. Sunulan olgular bazında, Behçet hastalığı ve malign lenfomanın olası ilişkisi konusunda literatür gözden geçirilmiştir. (Turk J Hematol 2011; 28: 327-34)

Anahtar kelimeler: Behçet hastalığı, malign lenfoma, radyoterapi, morbidite

\section{Introduction}

Behçet's disease (BD) was first described by Dr. Hulusi Behçet in 1937 as a triad of recurrent aphthous ulceration of oral and genital mucosa, and relapsing hypopyon uveitis [1]. It is now recognized as a multisystem inflammatory disorder characterized by vasculitis [2]. Although the exact etiology of BD is unknown, some genetic, immunologic, and infectious factors are suspected in the pathogenesis [3]. The treatment of BD is empirical and usually includes systemic corticosteroids, and immunosuppressive and/or cytotoxic agents [4]. The literature contains few reports of the coexistence of malignant disease in BD patients-to date only 96 cases (excluding myelodysplastic syndromes) have been reported, of which 17 are lymphoid malignancy [5-19]. Malignant transformation in BD might be due to the autoimmune nature of $\mathrm{BD}$, triggering infectious agents, or the drugs used for the management of $\mathrm{BD}$.

\section{Case Reports}

\section{Case 1}

A 53-year-old male patient was diagnosed as uveitis in 1979 (at the age of 26 years), due to hazy vision and impaired visual acuity; periorbital steroid injections were subsequently administered. Six months following the diagnosis of uveitis, recurrent oral and genital aphthous ulcers, and papulopustular skin lesions on the nape of the neck, back, and chest were observed; therefore, the patient was subsequently diagnosed as BD and treated with cyclophosphamide and prednisolone for 3 years.

In February 1998, bilateral enlargement of multiple lymph nodes in the neck was noted. Evaluation of the cervical lymph node biopsy specimen showed nodular lymphocyte-predominant Hodgkin's disease (HD) (Figure 1). Computed tomography (CT) of the thorax and abdomen were normal, and bone marrow aspiration was negative. Based on the diagnosis of stage II-B HD, vincristine, epirubicine, etoposide, and prednisolone (VEEP) combination chemotherapy was administered by the medical oncology department.

During the course of chemotherapy both the number and frequency of oral lesions increased. Following 8 courses of chemotherapy the patient achieved complete remission and was followed-up. In August 2005 the patient was restaged due to the observation of enlarged lymph nodes in the right axilla. Thoracic CT showed multiple enlarged lymph nodes in the right axilla and left supraclavicular fossa. Abdominopelvic CT was considered normal. Four courses of doxorubicin, bleomycin, vinblastin, and dacarbazine (ABVD) combination chemotherapy were administered, and complete remission was achieved.

The patient presented to our department for the first time in December 2005 for consolidative radiotherapy (RT). The lower neck, bilateral infrasupraclavicular fossa, bilateral axilla, and upper mediastinum were irradiated with cobalt 60 photons using a Theratron $780 \mathrm{C}$ cobalt linear accelerator (Best Theratronics LTD., Ontario, Canada). A total dose of 30.6 Gy was delivered in fractions of $1.8 \mathrm{~Gy} / \mathrm{d}$. During and after the RT no early toxicity associated with RT was observed, except for grade 1 hyperemia of the skin and dysphagia. Interestingly, the patient complained of a burning sensation at the irradiated region a few weeks after the completion of RT, but physical examination was unremarkable. One week later the burning sensation spontaneously abated. At the time this report was written the patient had been followed-up diseasefree for 4 years post RT and late toxicity associated with RT was not observed. The patient has complete vision loss in the right eye and stable partial vision loss in the left eye associated with BD. Oral and genital ulcers erupt every 2-3 weeks, and disappear 2-3 d later. 


\section{Case 2}

A 67-year-old male patient was first diagnosed as $\mathrm{BD}$ at age 44 years due to uveitis in the right eye, oral aphthous ulcers, scrotal ulcers, and pseudo follicular skin lesions that erupted once a week. As such, the patient was treated with colchicine. In February 2002 the patient complained of swelling on the left side of his neck and difficulty swallowing. CT of the head and neck showed a mass lesion in the left tonsillar fossa and multiple enlarged lymph nodes in the left cervical region. A biopsy specimen obtained from the left tonsil was evaluated as high-grade malignant lymphoma, diffuse large B-cell-type (Figure 2). CT of the thorax and abdomen, and bone marrow aspiration were negative.

The patient presented to our department for the first time in September 2002 for RT. The Waldeyer field and bilateral neck were irradiated with cobalt 60 photons using a Theratron $780 \mathrm{C}$ cobalt linear accelerator (Best Theratronics LTD., Ontario, Canada). A total dose of 45 Gy was delivered in fractions of $1.8 \mathrm{~Gy} \mathrm{~d}^{-1}$. During and after RT no early toxicity associated with RT was observed, except for grade 1 hyperemia of the skin, mucositis, and dysphagia. Following RT, 4 courses of cyclophosphamide, doxorubicin, vincristine, and prednisone (CHOP) combination chemotherapy were administered. At the time this report was written the patient had been followed-up disease-free for 7 years post RT and no late toxicity associated with RT was observed, except for grade 1 xerostomia. The patient has not used colchicine since 2003 and has complete vision loss in the right eye associated with $\mathrm{BD}$. Oral and genital ulcers erupt every 2-3 d, and disappear 2-3 d later.

\section{Discussion}

BD is a chronic, relapsing multisystem connective tissue disorder characterized by vasculitis in the mucocutaneous, ocular, gastrointestinal, respiratory, neurologic, urogenital, articular, and cardiovascular systems [20]. Other connective tissue disorders, including Sjögren's syndrome, dermatomyositis, rheumatoid arthritis, and systemic lupus erythematosus, are known to be associated with malignancy [21-23], and this association has been further

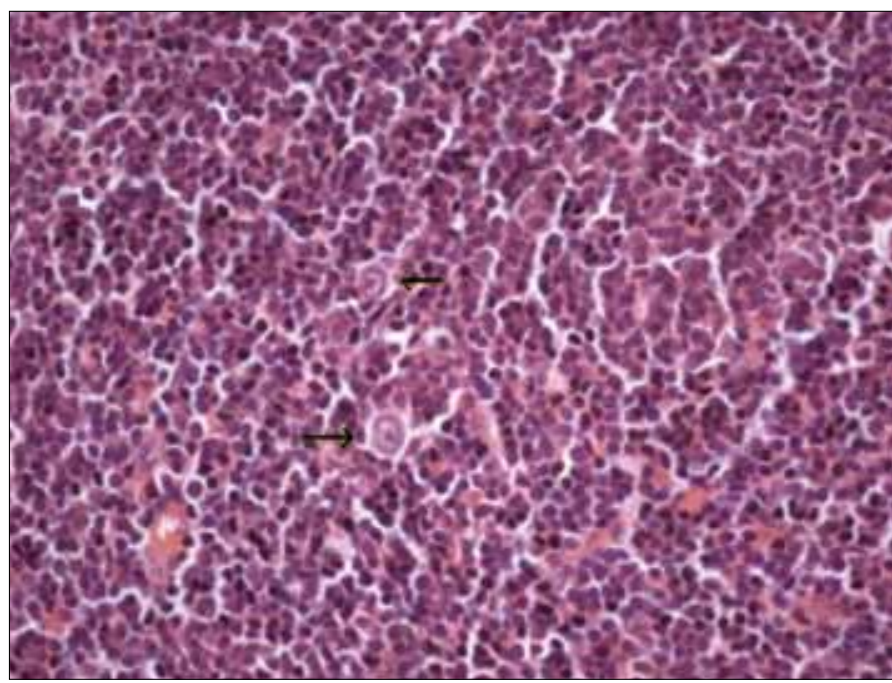

Figure 1. Microscopic Appearance of Mononuclear Hodgkin's Cells (Arrows) Infiltrating the Paracortical Lymphoid Tissue Between the Follicular Region (H\&E, 200×)

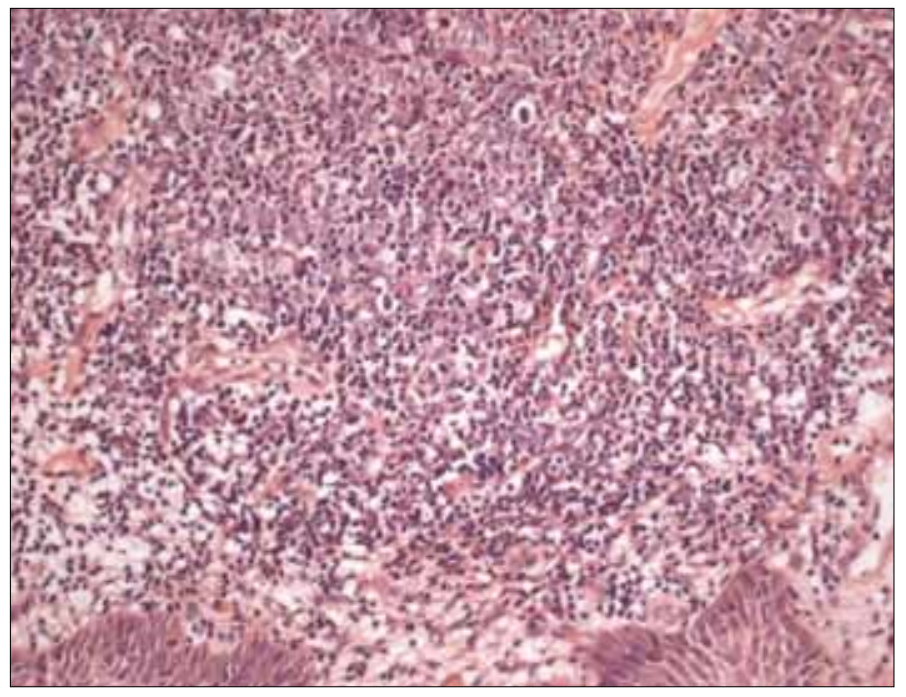

Figure 2. Microscopic Appearance of Tonsil Infiltrated By Malignant Lymphoma (H\&E, 200×)

supported by recent epidemiologic research. Nevertheless, the worldwide prevalence of BD and the possible association between malignant diseases and BD remain unclear. Only 96 cases of malignancy associated with BD have been reported; 63 cases had solid organ tumors, 16 cases had hematological malignancies, and 17 cases had lymphoid malignancies [5-19] (Table 1).

$\mathrm{BD}$ is one of the most common forms of vasculitis in the Turkish population; the reported prevalence varies from $80 / 100,000$ to $370 / 100,000$ [4]. Cengiz et al. [13] reported $400 \mathrm{BD}$ patients during a 13-year period; malignancy developed in 13 (3.25\%) patients, $2(0.5 \%)$ of which had malignant lymphoma. A study that included $387 \mathrm{BD}$ patients from 
Table 1. Reported Cases of Malignant Lymphoma Associated with Behçet's Disease

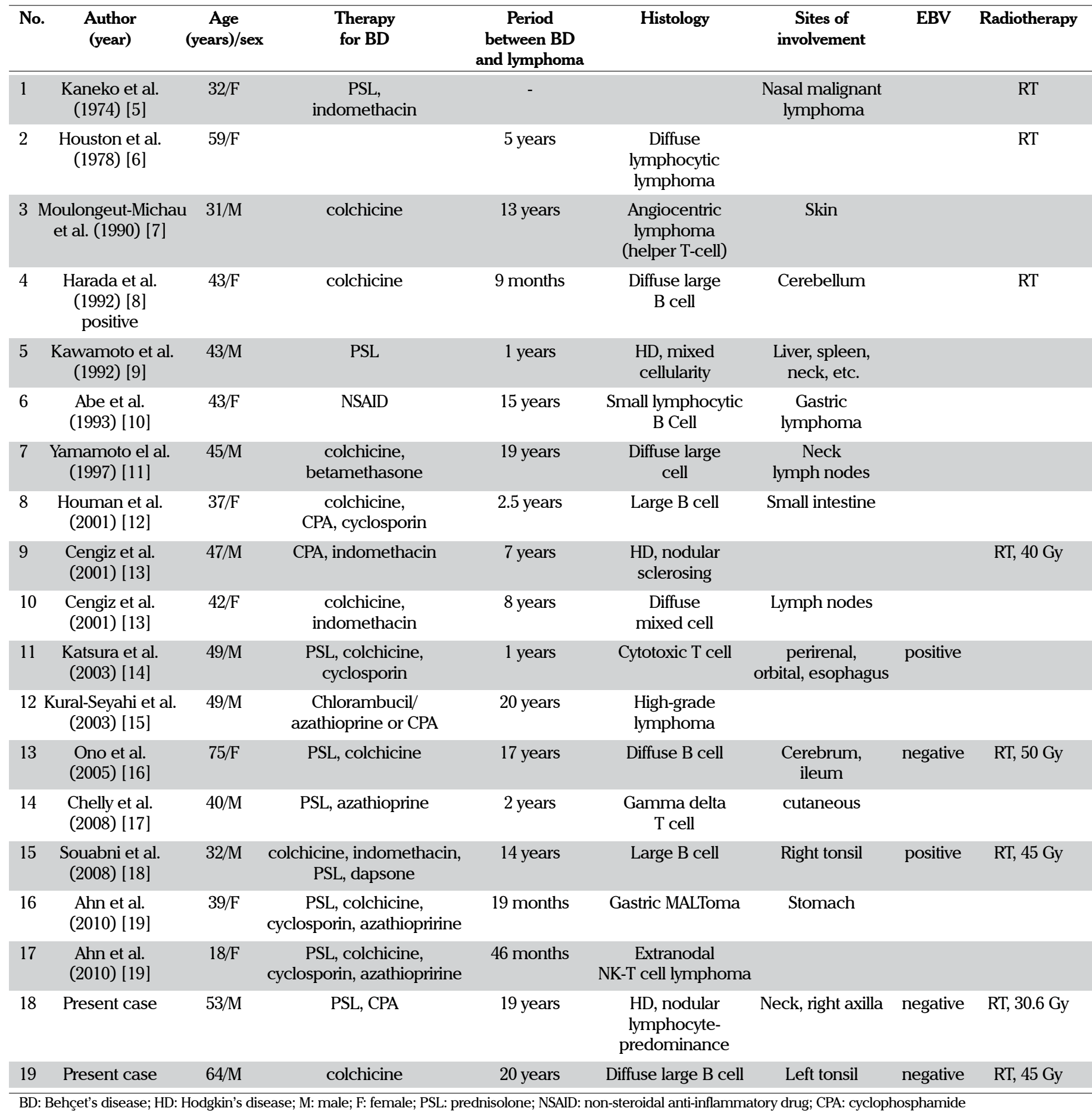

Turkey reported that $8(2.06 \%)$ patients developed malignancy during 20 years of follow-up, 1 (0.51\%) of which was diagnosed as malignant lymphoma [15]. Between 1992 and 2007, 440 patients with malignant lymphoma presented to our department, of which only $2(0.45 \%)$ were previously diagnosed with BD.
Case 1 is only the third case of HD associated with BD to be reported. The previously reported cases of HD associated with BD were mixed cellularity type $(n=1)$ and nodular sclerosing type $(n=1)$ $[9,13]$, whereas the histopathological subtype was nodular lymphocyte predominant in case 1 . The previous mixed cellularity-type case was treated 
with prednisolone only, and the previous nodular sclerosing-type case was treated with cyclophosphamide and indometacin for $\mathrm{BD}$, whereas case 1 was treated with prednisolone and cyclophosphamide.

Previous reports of malignant lymphoma associated with $\mathrm{BD}$ are mostly extranodal, whereas only 2 cases had nodal involvement $[11,13]$. Case 2 is considered by us to be the 16th reported case of malignant lymphoma associated with $\mathrm{BD}$ and only the 2nd case of tonsil involvement; the treatment for BD in this patient was colchicine.

The pathogenesis of BD remains to be discerned, although infectious, immunologic, and genetic factors have been implicated [20]. The pathophysiology of BD is considered to involve excess function of neutrophils, vascular damage associated with thrombus formation, and lymphocyte dysfunction [24]. The major immunologic features of BD are increased T-cell and B-cell response to heat-shock proteins, increased neutrophil activity, and alteration in cytokine levels [4]. Additionally, helper T-cells and macrophages are known to exhibit immunological dysfunction, as well as neutrophils [10]. Development of malignancy in autoimmune diseases and vasculitides could be related to immune regulation abnormality, T-cell deficiency, or over proliferation of B-cells, which may trigger the malignant transformation of cells [20]. Moreover, the above-mentioned immunological features of BD might be associated with the development of malignancy.

All BD cases are devoid of any documented cause of lymphoid malignancy, other than the possibility of drug-induced etiology, the immunological features of $\mathrm{BD}$, or immune system stimulation via an infectious agent. Several genetic diseases, and environmental and infectious agents have been associated with the development of lymphoma [25]. The frequency of non-Hodgkin's lymphoma is much higher in immunocompromised patients [26]. Patients with autoimmune and chronic inflammatory disorders have an increased risk for the development of non-Hodgkin's lymphoma [27]. In non-Hodgkin's lymphoma, as in BD, disturbances in T-cell compartment and T-cell dysfunctionincluding low autologous mixed lymphocyte reaction-have been reported [10]; therefore, between
BD and development of lymphoma may be a relationship. Cohort studies and meta-analyses show that non-Hodgkin's lymphoma is more common in patients with autoimmune diseases, especially those with Sjögren's syndrome, systemic lupus erythematosus, and rheumatoid arthritis, than in the general population; however, such data are not available for BD [27,28]. Immunosuppressive agents are thought to be involved in the pathophysiology of malignancy [29]. Numerous studies have implicated the use of immunosuppressive agents, such as chlorambucil, cyclophosphamide, and colchicine, in the etiology of lymphoma transformation in BD. Previous research reports that there is a significantly elevated risk of lymphoma in association with use of non-steroidal anti-inflammatory drugs, corticosteroids, and other immunosuppressants [30].

Steroids inhibit the activation and growth of T-cells, and reduce the number of peripheral lymphocytes. Steroids also inhibit B-cell maturation at an early stage by inhibiting interaction between monocytes and T-cells [16]. The exact mechanism of the steroid function is not known, but all steroid characteristics might be related to late onset malignant lymphoma [16]. Colchicine is usually prescribed for mucocutaneous disease, arthritis, and genital ulcers [4]; this drug suppresses phagocytosis and emigration of white blood cells, and inhibits chemotactic responses of neutrophils to chemotactic cytokines [16]. Sauabni et al. [18] also attributed lymphoma transformation to the mutagenic effect of colchicine in animals. Long-term administration of colchicine in patients with BD may induce malignant lymphoma. Cyclophosphamide is usually used to treat $\mathrm{BD}$ patients that are unresponsive to other therapies [4]. Long-term treatment of autoimmune disease patients with alkylating agents (e.g. cyclophosphamide) might result in secondary neoplastic disease; therapy-related myelodysplasia/acute myeloid leukemias are a well-known consequence, yet therapy-related lymphomas are less well-known in patients with autoimmune disease [31]. The period between the onset of BD and malignant lymphoma varies from 9 months to 20 years, and immunosuppressive agents and steroids have not been administered in all reported cases (Table 1). Moreover, following transplantation and treatment 
of collagen disease with immunosuppressive drugs, most malignancies arise within 6 months [16]. Thus, it is difficult to discern if the effects of immunosuppressive agents used in the treatment or the underlying immune mechanism are responsible for the association between $\mathrm{BD}$ and malignant lymphoma.

Immune system stimulation via an infectious agent has been suggested to play a role in the pathogenesis of $\mathrm{BD}$ [4]. Infectious agents are also implicated in the pathogenesis of Hodgkin's and non-Hodgkin's lymphoma [25,32]. Epstein-Barr virus (EBV) infection is associated with neoplastic proliferation in immunosuppressed transplant recipients [33]. Of the 15 cases of malignant lymphoma associated with BD previously reported, 3 of the 4 that were tested for EBV infection were positive $[8,14,18]$. In the presented cases, immunohistochemical staining on paraffin tissues did not indicate the presence of EBV (anti-EBV/LMP Ab-1, ms-1458, Thermo Fisher Scientific, Pittsburgh, PA). Moreover, EBV infection is associated, in particular, with mixed cellularity-type HD [32]; Only 1 previously reported case of HD associated with BD was mixed cellularity-type.

Another point is use of radiation for the treatment of malignancy in BD. Numerous studies report that CVD predisposes patients to increased toxicity from therapeutic irradiation [34-38]; however, considering the effects of RT in patients with $\mathrm{BD}$, the literature is lacking sufficient data, as there are only a few reports on the use of radiation in $\mathrm{BD}$ patients. In a part of these reports, the authors had not been referred to radiation toxicity $[16,18,20,39]$. Lowdose total lymphoid irradiation treatment in 5 patients with intractable BD was reported; no morbidity related to irradiation occurred, presumably because of the relatively low doses used [13].

Strohal et al. [40] reported a BD patient treated with a combination of chemotherapy and 40-Gy of radiation administered to the heart, and cervical and mediastinal lymph nodes for treatment of comorbid multicentric Castleman's disease. The researcher reported that the treatment was welltolerated, but did not discuss radiation toxicity. Cengiz et al. [13] treated 6 BD patients with RT due to malignant disease, and reported that there wasn't an increase in the incidence or severity of acute radiation morbidity. In all, 3 of the 6 patients ( 1 with HD, 1 with a malignant mesenchymal tumor, and 1 with ureteral fibrosis) developed late radiation reactions, including brachial plexopathy and dermal necrosis. Recently, Chargari et al. [41] reported adjuvant whole-breast RT for left breast ductal carcinoma in situ in a patient with quiescent BD. At a dose of $44 \mathrm{~Gy}$ acute grade 3 radioepithelitis occurred, which necessitated cessation of RT. The researchers reported that the radiation-induced vascular lesions were similar to the vasculitis observed in BD. In the presented cases we did not observe an increase in the severity of acute or late reactions related to irradiation, perhaps because of the relatively low total doses administered.

Malignant lymphoma associated with $\mathrm{BD}$ is very rare. For the development of lymphoid malignancy in $\mathrm{BD}$ or, to establish an association between these 2 diseases, the roles of immunologic factors or, drugs used for the treatment or, infectious agent are not clear yet. Due to the above-mentioned disturbances or, indeterminate other factors, there may be an association between BD and malignant lymphoma, but this may also be a hazardous coincidence. Based on all available data, it is difficult to conclude that RT increases the incidence and severity of radiation reactions in BD patients; however, doses exceeding $40 \mathrm{~Gy}$, especially in patients with active $\mathrm{BD}$, should be administered with caution.

\section{Conflict of interest statement}

The authors of this paper have no conflicts of interest, including specific financial interests, relationships, and/or affiliations relevant to the subject matter or materials included.

\section{References}

1. Behcet $\mathrm{H}$. Uber rezidivierende aphtose, durch ein virus verursachte Geschewure am Mund, am Auge und an den genitelian. Dermatol Wschr 1937;105:1152-7.

2. Koç Y, Güllü I, Akpek G, Akpolat T, Kansu E, Kiraz S, Batman F, Kansu T, Balkanci F, Akkaya S. Vascular involvement in Behcet's Disease. J Rheumatol 1992;19:402-10.

3. Zierhut M, Mizuki N, Ohno S, Inoko H, Gül A, Onoé K, Isogai E. Immunology and functional genomics of Behçet's disease. Cell Mol Life Sci 2003;60: 1903-22. [CrossRef] 
4. Al-Otaibi LM, Porter SR, Poate TWJ. Behçet's disease: a rewiev. J Dent Res 2005;84:2009-22. [CrossRef]

5. Kaneko H, Hojo Y, Nakajima H, Okamura A, Fukase M, Katano A. Behçet syndrome associated with nasal malignant lymphoma - report of an autopsy case. Acta Pathol Jpn 1974;24:141-50.

6. Houston KA, O'duffy JD, McDuffie FC. Behçet's disease associated with a lymphoproliferative disorder, mixed cryoglobulinemia, and an immune complex mediated vasculitis. J Rheumatol 1978;5:217-23.

7. Moulonguet-Michau I, Blanc F, Cavalier Balloy B, Price P, Flaqeul B, Civatte J. Angiocentric lymphoma in Behçet's disease. Ann Dermatol Venereol 1990;117: 885-7.

8. Harada K, Ohtsuru K, Nakayama K, Takagi S, Sugiata Y, Torigoe R. Intracranial primary malignant lymphoma following Behcet's disease-case report. No To Shinkei 1992;44:1029-33.

9. Kawamoto S, Terada H, Niikura H, Kumasaka T, Saiki S. Hodgkin's Disease associated with Behçet's disease. Rinsho Ketsueki 1992;33:211-5.

10. Abe T, Yachi A, Yabana T, Ishii Y, Tosaka M, Yoshida Y, Yonezawa K, Ono A, Ikeda N, Matsuya M, Hayashi T, Tokunoh T, Yawata A, Sasaki S, Aoki S, Sugiyama T. Gastric non-Hodgkin's lymphoma associated with Behçet's disease. Am Intern Med 1993;32:663-7. [CrossRef]

11. Yamamoto T, Tamura M, Hamauzu T, Nakayama A, Kawasugi K, Kamakura M, Kinoshita T, Kuyama Y, Yamanaka M, Wang LM, Sanaka M, Mineshita S. Intestinal Behçet's disease associated with non-Hogkin's lymphoma. J Gastroenterol 1997;32:241-5. [CrossRef]

12. Houman MH, Ben Ghorbel I, B'Chir-Hamzaoui S, Lamloum M, Kchir N, Miled M. Intestinal lymphoma associated with Behçet's disease. Ann Med Interne (Paris) 2001;152:415-8.

13. Cengiz M, Altundag MK, Zorlu AF, Güllü IH, Ozyar E, Atahan IL. Malignancy in Behcet's disease: a report of 13 cases and review of the literature. Clin Rheumatol 2001;20:239-44. [CrossRef]

14. Katsura Y, Suzukawa K, Kojima H, Yoshida C, Shimizu S, Mukai H, Hasegawa Y, Imagawa S, Mori N, Nagasawa T. Cytotoxic T-cell lymphoma arising in Behçet's disease. Int J Hematol 2003;77:282-5. [CrossRef]

15. Kural-Seyahi E, Fresko I, Seyahi N, Ozyazgan Y, Mat C, Hamuryudan V, Yurdakul S, Yazici H. The long-term mortality and morbidity of Behçet Syndrome. A 2-decade outcome survey of 387 patients folloved at dedicated center. Medicine (Baltimore) 2003;82:60-76. [CrossRef]

16. Ono Y, Yamada M, Kawamura T, Ito J, Kanayama S, Katayama Y, Okusawa E. Central Nervous System Malignant Lymphoma associated with Behçet's disease. Neurol Med Chir 2005;45:586-90. [CrossRef]

17. Chelly I, Limaïem F, Mekni A, Bellil S, Bellil K, Ghorbel IB, Haouet S, Zitouna M, Kchir N. Cutaneous gammadelta T-cell lymphoma arising in the setting of Behcet's disease. Pathologica 2008;100:166-9.
18. Souabni L, Elleuch M, Amira C, Sellami S. Malignant lymphoma of the tonsil in a patient with Behçet's disease. Joint Bone Spine 2008;75:616-61. [CrossRef]

19. Ahn JK, Oh AJ, Lee J, Koh EM, Cha HS. Behcet's disease associated with malignancy in Korea: a single center experience. Rheumatol Int 2010;30:831-5. [CrossRef]

20. Kaklamani VG, Tzonou A, Kaklamanis PG. Behçet's disease associated with malignancies. Report of two cases and review of the literature. Clin Exp Rheumatol 2005;23:35-41.

21. Black KA, Zilko PJ, Dawkins RL, Armstrong BK, Mastaglia GL. Cancer in connective tissue disease. Arthritis Rheum 1982;25:1130-3. [CrossRef]

22. Barnes BE. Dermatomyositis and malignacy: a review of the literature. Ann Intern Med 1976;84:68-76.

23. Canoso JJ, Cohen AS. Malignancy in a series of 70 patients with SLE. Arthritis Rheum 1974;17:383-8. [CrossRef]

24. Sakane T, Takeno M, Suzuki N, Inaba G. Behcet's disease. N Engl J Med 1999;342:1284-91. [CrossRef]

25. Prosnitz LR, Ng A. Non-Hodgkins lymphoma. In: Halperin EC, Perez Ca, Brady LW, eds. Principles and Practice of Radiation Oncology. 5th ed. Philadelphia: Lippincott Williams and Wilkins, 2008:1739-65.

26. Gotschalk S, Rooney CM, Heslop HE. Post-transplant lymphoproliferative disorders. Annu Rev Med 2005;56:29-44. [CrossRef]

27. Zintzaras E, Voulgarelis M, Moutsopoulos HM. The risk of lymphoma development in autoimmune diseases a meta-analysis. Arch Intern Med 2005;165:2337-44. [CrossRef]

28. Martin DN, Mikhail IS, Landgren O. Autoimmunity and hematologic malignancies: associations and mechanism. Leuk Lymphoma 2009;50:541-50. [CrossRef]

29. Celik I, Altundağ K, Erman M, Baltali E. Cyclophosphamide-associated carcinoma of urinary bladder in Behcet's disease. Nephron 1999;81:239.

30. Chang ET, Smedby KE, Hjalgrim H, Schöllkopf C, Porwit-MacDonald A, Sundström C, Tani E, d'Amore F, Melbye M, Adami HO, Glimelius B. Medication use and risk of non-Hodgkin's lymphoma. Am J Epidemiol 2005;162:965-74. [CrossRef]

31. Au WY, Ma ES, Choy C, Chung LP, Fung TK, Liang R, Kwong YL. Therapy-related lymphomas in patients with autoimmune diseases after treatment with disease-modifying anti-rheumatic drugs. Am J Hematol 2006;81:5-11. [CrossRef]

32. Hoppe RT. Hodgkin Lymphoma. In: Halperin EC, Perez Ca, Brady LW, eds. Principles and Practice of Radiation Oncology. 5th ed. Philadelphia: Lippincott Williams and Wilkins, 2008:1721-38.

33. Hsieh WS, Lemas MV, Ambinder RF. The biology of Epstein-Barr virus in post-transplant lymphoproliferative disease. Transpl Infect Dis 1999;1:204-12. [CrossRef]

34. Morris MM, Powell SN. Irradiation in the setting of collagen vascular disease: acute and late complications. J Clin Oncol 1997;15:2728-35.

35. De Neayer B, De Meerleer G, Braems S, Vakaet L, Huys J. Collagen vascular diseases and radiation therapy:a critical review. Int J Radiat Oncol Biol Phys 1998;44:975-80. 
36. Ross JG, Hussey DH, Mayr NA, Davis CS. Acute and late reactions to radiation therapy in patient with collagen vascular disease. Cancer 1993;71:3744-52. [CrossRef]

37. Varga J, Haustein UF, Creech RH, Dwyer JP, Jimenez SA. Exaggerated radiation induce fibrosis in patients with systemic sclerosis. JAMA 1991;265:3292-5. [CrossRef]

38. Phan C, Mindrum M, Silverman C. Matched-control retrospective study of the acute and late complications in patients with collagen vascular diseases treated with radiation therapy. Cancer J 2003;9:461-6. [CrossRef]

39. Satolli F, Venturi C, Vescovi V, Morrone P, De Panfilis G. Merkel-cell carcinoma in Behçet's disease. Acta Derm
Venereol 2005;85:79. [CrossRef]

40. Strohal R, Tschachler E, Breyer S, Uthman A, Simonitsch I, Tratting S, Scheithauer W, Stingl G, Kornek GV. Reactivation of Behçet's disease in the course of multicentric HHV8-positive Castleman's disease: longterm complete remission by a combined chemo/radiation and interferon- $\alpha$ therapy regimen. Br J Haematol 1998;103:788-90. [CrossRef]

41. Chargari C, Kirova YM, Fourquet A, Campana F. Severe acute radiation-related skin toxicity in a breast cancer patient with Behçet's disease. Radiother Oncol 2009;91:139. [CrossRef] 